\title{
Soft Tissue Sarcoma of the Abdomen and Thoracic Visceral Organs pT1 TNM Finding v8
}

National Cancer Institute

\section{Source}

National Cancer Institute. Soft Tissue Sarcoma of the Abdomen and Thoracic Visceral

Organs pT1 TNM Finding v8. NCI Thesaurus. Code C136734.

Soft tissue sarcoma of the abdomen and thoracic visceral organs, org an confined. (from AJCC 8th Ed.) 